\title{
Evaluation of Lingual Frenulum Using Geometric Morphometrics
}

\author{
Evaluación del Frenillo Lingual Utilizando Morfometría Geométrica
}

"Dundar Kacar; **Fethiye Cakmak; ***A Aslı Dogan; ${ }^{* * * * *}$ Ozdemir Sevinc \& *Cagatay Barut

KACAR, D.; CAKMAK, F.; DOGAN, A.; SEVINC, O. \& BARUT, C. Evaluation of lingual frenulum using geometric morphometrics. Int. J. Morphol., 29(2):313-317, 2011.

SUMMARY: A fold of tissue, the lingual frenulum, extends onto the inferior surface of the tongue from near the base of the tongue on midline. The shape, length and alignment of lingual frenulum vary between individuals. The aim of this study is to evaluate morphology of lingual frenulum with respect to gender. Ninety seven volunteers who were students and employees of Zonguldak Karaelmas University, School of Medicine participated in the study. Two individuals with a history of hepatitis and 20 individuals with inadequate photographs were excluded from the study. Morphometric analyses were performed on the photographs of 75 volunteers (36 men, 39 women). Lingual frenulum photograph of each individual was taken using standard photographic techniques. The individual opened his/her mouth as much as possible with the tongue in contact with the interior surface of the two middle incisors. The morphology of the lingual frenulum was evaluated with linear measurements and geometric morphometrics methods. The length of lingual frenulum between the attachments of it, to the floor of the mouth and the inferior surface of the tongue were measured using Digimizer software. Four reference points determined previously were marked by tpsDig2 software on photographs. This process was repeated for each sample to create a txt file containing reference points of 75 individuals. Statistical analysis of txt files were carried out using Morpheus software. There were no statistically significant differences between the linear measurements of lingual frenulum according to gender ( $p>0.05$ ). Lingual frenulum had no gender differences according to geometric morphometrics analysis as well $(\mathrm{p}>0.05)$. It can be suggested that lingual frenulum had similar architecture in both sexes.

KEY WORDS: Lingual frenulum; Geometric morphometrics; Men; Women; Reference points.

\section{INTRODUCTION}

The physiological evolution of tongue with the other structures in the oral cavity is very important in terms of speech (Fletcher \& Meldrum, 1968). The mucosa that covers the bottom surface of the tongue spreads through the floor of the mouth and from there to the gums. The fold of this mucosa in the midline is called lingual frenulum (Arıncı \& Elhan, 2006). Lingual frenulum differs from one individual to another in terms of shape, length and location (Kotlow, 1999). The purpose of this study is to evaluate the structure of lingual frenulum according to gender and to determine the differences -if there are anyby means of geometric morphometrics.

\section{MATERIAL AND METHOD}

This study was performed with the participation of 97 volunteers who were students and staff of Zonguldak Karaelmas University, School of Medicine. Due to positive hepatitis history in two volunteers, and due to the technical errors in their mouth photographs, 20 volunteers were excluded from the study. The analysis were performed on 75 people; 39 women (group 1) and 36 men (group 2). The mouth opening of individuals was measured via digital compass. In this study, to minimize the changes due to the soft tissue characteristic of the sublingual area, the mouth photographs of the participants were taken while the mouth was maximally opened, and the tip of the tongue was in

\footnotetext{
Department of Anatomy, School of Medicine, Zonguldak Karaelmas University, Zonguldak, Turkey.

** Department of Orthodontics, Faculty of Dentistry, Zonguldak Karaelmas University, Zonguldak, Turkey.

${ }^{* * *}$ Department of Anthropology, Faculty of Arts and Sciences, Ahi Evran University, Kirsehir, Turkey.

***** Department of Anatomy, School of Medicine, Canakkale Onsekiz Mart University, Canakkale, Turkey.
} 
touch with the posterior surface of upper central incisors. Two photographs of the lingual frenulum (front and lateral views) were taken using standard photography techniques (Fig. 1). The position of the lingual frenulum used in this study is stated to be the most appropriate position by Marchesan (2005).

On the photographs, the distance between starting point of lingual frenulum at the floor of the mouth and the place where it stuck to the tongue was measured linearly and the area of the frenulum within those reference points was measured using Digimizer software (Fig. 2). The linear measurement values were evaluated with independent sample test.
Geometric morphometrics, which is an efficient and accurate method, was preferred to evaluate lingual frenulum using the mouth photographs (Monterio, 2000). This method was reported to be more efficient than classical/traditional morphometry (Kekecoglu et al., 2007).

Previously determined 4 reference points were marked on the photographs using tpsDig2 software (Fig. 3), and for the geometric morphometrics analysis, this procedure was repeated for each sample, and at the end, text documents including the coordinates of the reference points for each 75 samples were created. The data in these text documents was analyzed statistically using Morpheus software.
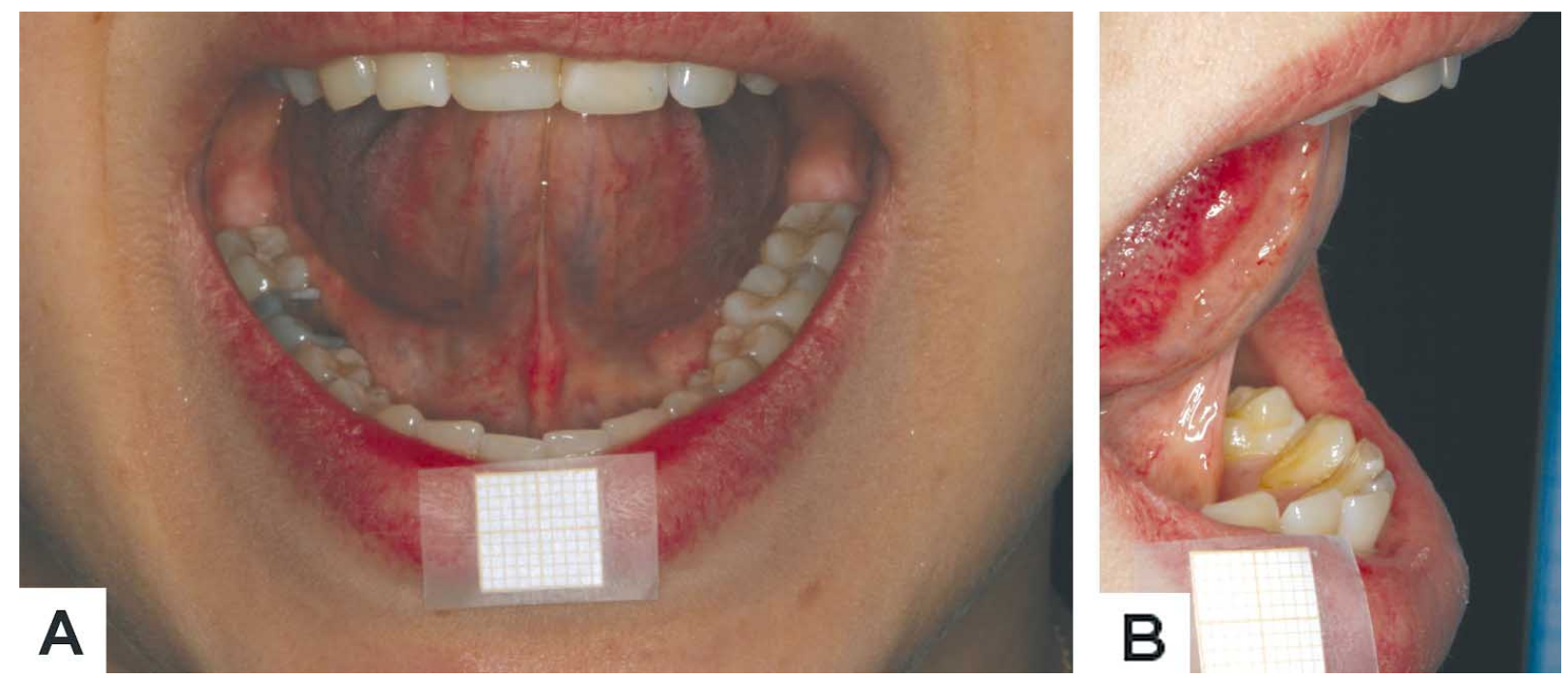

Fig. 1. Lingual frenulum photograph taken while the mouth was maximally opened, and the tip of the tongue was touching to the posterior surface of upper central incisors. A: From the front; B: Lateral

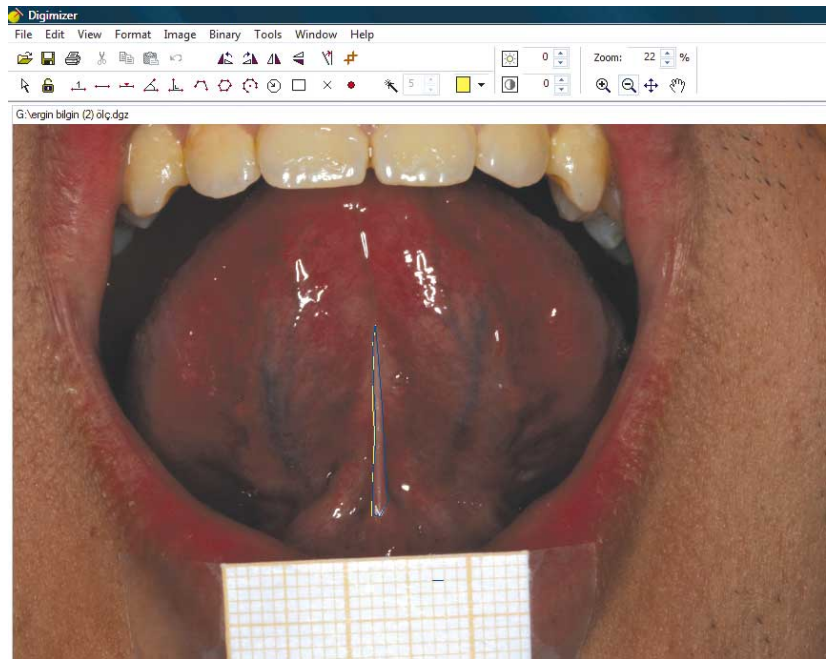

Fig. 2. Linear measurement of lingual frenulum using Digimizer software.

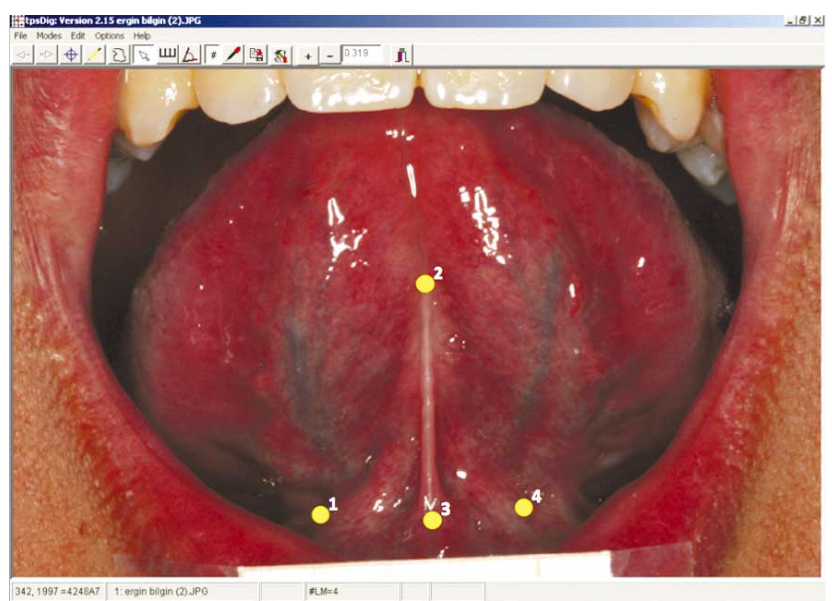

Fig. 3. The reference points on documents created by TpsDig and TpsUtil softwares. 1. The intersection point of lateral margin of the lingual frenulum with the floor of the mouth on the right side. 2 . Uppermost point of lingual frenulum. 3. Bottom point of lingual frenulum. 4. The intersection point of lateral margin of the lingual frenulum with the floor of the mouth on the left side. 


\section{RESULTS}

In our study, the maximum mouth opening distance measured using a digital compass was 38.3-63.8 $\mathrm{mm}$ in men and 32.4-56.9 $\mathrm{mm}$ in women. The maximum mouth opening while the tip of the tongue touching the posterior surface of upper central incisors was found to be $29.7-46.8 \mathrm{~mm}$ in men and 22.2-42.4 $\mathrm{mm}$ in women. The average length value of lingual frenulum measured in the photographs was $13.99 \mathrm{~mm}$ in men and $13.44 \mathrm{~mm}$ in women. Area value was found to be $10.14 \mathrm{~mm}^{2}$ in men, $10.24 \mathrm{~mm}^{2}$ in women on the average. When these lengths and area values, obtained by linear measurements, were compared according to gender, no statistically significant differences were found $(\mathrm{p}>0.05)$ (Table I).

Depending on the geometric morphometrics analysis, the shape diversity was reflected on deformation grids. The points where the shape diversity concentrates were identified via TPSspline software, and the deformation grids of the groups were compared; however no significant deformations were observed (Fig. 4). Results of the Manova test indicated that the differences between the two groups were not statistically significant ( $>0.05$ ) (Table II).

Table I. Comparison of values obtained using traditional morphometry on the mouth photographs according to gender.

\begin{tabular}{llllllll}
\hline & \multicolumn{9}{l}{ Men $(\mathbf{n}=36)$} & \multicolumn{2}{l}{ Women $(\mathbf{n = 3 9})$} \\
\hline & Mean & SD & Mean & SD & t & df & p \\
\hline frenulum length $(\mathrm{mm})$ & 13.99 & 4.13 & 13.44 & 3.57 & 0.627 & 73 & 0.532 \\
lingual frenulum $\left(\mathrm{mm}^{2}\right)$ & 10.14 & 4.57 & 10.24 & 7.19 & -0.069 & 73 & 0.945 \\
\hline
\end{tabular}

\begin{tabular}{|c|c|c|c|}
\hline Effect: Group & Group & & \multirow{5}{*}{$\begin{array}{l}\text { Table II. Comparison of } \\
\text { the coordinate values of } \\
\text { the reference points } \\
\text { using Manova analysis. }\end{array}$} \\
\hline Groups & $\begin{array}{l}1 \\
(\mathrm{n}=39) \\
2 \\
(\mathrm{n}=36)\end{array}$ & & \\
\hline Alpha & 0.050 & & \\
\hline nDim & 2 & & \\
\hline nPts & 4 & & \\
\hline Stats & det & trace & maxRoot \\
\hline Total SS & 0.000 & 2.614 & $4 \quad 1.943$ \\
\hline Unexplained SS & 0.000 & 2.597 & $7 \quad 1.931$ \\
\hline Explained SS & 0.000 & 0.016 & $5 \quad 0,016$ \\
\hline P > Explained SS & 0.708 & 0.625 & 0.625 \\
\hline
\end{tabular}

Table III. Mouth opening values obtained from different studies.

\begin{tabular}{lcc}
\hline & $\begin{array}{c}\text { Maximum mouth } \\
\text { opening (mm) }\end{array}$ & $\begin{array}{c}\text { Maximum mouth } \\
\text { opening with the } \\
\text { tongue is in touch } \\
\text { with incisive papilla } \\
(\mathbf{m m})\end{array}$ \\
\hline Marchesan & $34.6-56.2$ & $20.5-44$ \\
Kaçar et al. & $32.4-61.3$ & $22.2-46.8$ \\
\hline
\end{tabular}

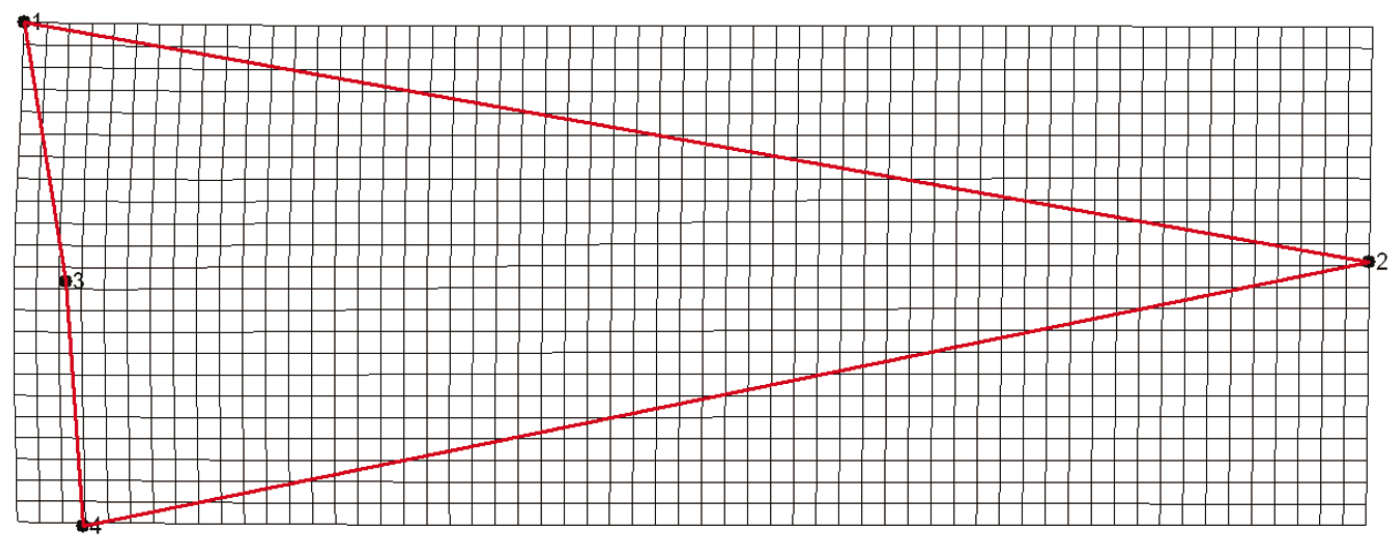

Fig. 4. Deformation grid of the lingual frenulum illustrating the consensus between genders with TPSsplin (scale factor 5). 


\section{DISCUSSION}

Many studies related to the mucosa folds in cavitas oris (frenulum of upper lip, frenulum of lower lip vs lingual frenulum) were conducted to date (Güldag et al., 2006; Amir et al., 2006; Agarwal \& Raina, 2003). Almost all of these studies were related to clinical approaches. Most of the studies on lingual frenulum were associated with the ankyloglossia (tongue-tie), a condition characterized by a situation where it is shorter than normal, and encompass the symptoms of this pathology and its treatment (Geddes et al., 2008; Messner et al., 2000; Ricke et al., 2005; Hall \& Renfrew 2005; Reamy et al., 2010; Klockars \& Pitkäranta, 2009; Ballard et al., 2002). In addition, lingual frenulum was used as a reference point in the evaluation of occlusion (Bissasu, 1999).

In our study, the structure, length and area of lingual frenulum were evaluated according to gender. There are several studies in the literature related with the length measurement of lingual frenulum: In the study of Kotlow frenulum measurements were performed on 322 children aged between 1-14 years with short frenulum. He divided the study group into 5 categories depending on the attachment site of the lingual frenulum to the tongue.
Similarly, in his quantitative study on 98 individuals who were older than 18, Marchesan, divided the lingual frenulum structure into two groups and carried frenulum measurements in these groups. The measurement results of mouth opening using a digital compass were similar to those of ours (Table III). Fletcher \& Meldrum conducted measurements using a digital compass on a group of children aged between 11-12 years and evaluated the relation between frenulum and logopathy; however, they did not state the measurement values of the lingual frenulum.

To our knowledge there is no other study in the literature in which the structure, length and area of lingual frenulum was evaluated according to sex. Depending on the results of the current study it can be suggested that the structure of lingual frenuluma doesn't show any differences according sex.

In conclusion, it is evident that many structures in human body have differences according to gender; however, it can be concluded that lingual frenulum has a similar structure in both genders.

KACAR, D.; CAKMAK, F.; DOGAN, A.; SEVINC, O. \& BARUT, C. Evaluación del frenillo lingual utilizando morfometría geométrica. Int. J. Morphol., 29(2):313-317, 2011.

RESUMEN: Un pliegue de tejido, el frenillo lingual, se extiende sobre la superficie inferior de la lengua cerca de su base en la línea mediana. La forma, la longitud y la alineación del frenillo lingual pueden variar entre los individuos. El objetivo de este estudio fue evaluar la morfología del frenillo lingual con respecto al sexo. Participaron en el estudio 97 voluntarios, estudiantes y empleados de la Facultad de Medicina de la Universidad Zonguldak Karaelmas. Dos individuos con antecedentes de hepatitis y 20 personas con fotografías inapropiadas fueron excluidas del estudio. El análisis morfométrico se llevó a cabo en las fotografías de 75 voluntarios (36 hombres y 39 mujeres). La fotografía del frenillo lingual de cada individuo fue tomada usando las técnicas fotográficas convencionales. Cada individuo abrió su boca tanto como fue posible con la lengua en contacto con la superficie interna de los dos incisivos centrales superiores. La morfología del frenillo lingual se evaluó con métodos de medidas lineales y morfometría geométrica. La longitud del frenillo lingual entre su origen e inserción del suelo de la boca a la superficie inferior de la lengua se midieron utilizando el software Digimizer. Cuatro puntos de referencia determinados previamente fueron marcados mediante el software tpsDig2 en cada fotografía. Este proceso se repitió en cada muestra para crear un archivo txt que contuviera los puntos de referencia de 75 personas. El análisis estadístico de los archivos txt se llevó a cabo utilizando el software Morpheus. No hubo diferencias estadísticamente significativas entre las mediciones lineales de frenillo lingual, en función del sexo ( $>0,05)$. El frenillo lingual no tuvo diferencias de sexo según el análisis de morfometría geométrica $(\mathrm{p}>0,05)$. Se puede sugerir que el frenillo lingual tiene una arquitectura similar en ambos sexos.

PALABRAS CLAVE: Frenillo lingual; Morfometría geométrica; Hombres; Mujeres; Puntos de referencia.

\section{REFERENCES}

Agarwal, P. \& Raina, V. K. Tongue-tie: an update. Indian Pediatr., 40(5):404-5, 2003.
Amir, L. H.; James, J. P. \& Donath, S. M. Reliability of the hazelbaker assessment tool for lingual frenulum function. Int. Breastfeed J., 1(1):3, 2006. 
Arınc1, K. \& Elhan, A. Anatomy. ${ }^{\text {th }}$ Ed. Ankara, Günes, 2006. p. 230.

Ballard, J. L.; Auer, C. E. \& Khoury, J. C. Ankyloglossia: assessment, incidence, and effect of frenuloplasty on the breastfeeding dyad. Pediatrics, 110(5):e63, 2002.

Bissasu, M. Use of lingual frenum in determining the original vertical position of mandibular anterior teeth. $J$. Prosthet. Dent., 82(2):177-81, 1999.

Fletcher, S. G. \& Meldrum, J. R. Lingual function and relative length of the lingual frenulum. J. Speech Hear Res., 11(2):382-90, 1968.

Geddes, D. T.; Langton, D. B.; Gollow, I.; Jacobs, L. A.; Hartmann, P. E. \& Simmer, K. Frenulotomy for breastfeeding infants with ankyloglossia: effect on milk removal and sucking mechanism as imaged by ultrasound. Pediatrics, 122(1):e188-94, 2008.

Güldag, M.Ü.; Sentut, F. \& Büyükkaplan, S. Üst bukkal frenulumlar arasi mesafe ile maksiller anterior disler arasındaki iliskinin incelenmesi. Atatürk Üniv. Dis. Hek. Fak. Derg., 16(3):14-8, 2006.

Hall, D. M. \& Renfrew, M. J. Tongue tie. Arch. Dis. Child., 90(12):1211-5, 2005.

Kekeçoglu, M.; Bouga, M.; Soysal, M. I. \& Harizanis, P. Morphometrics as a tool for the study of genetic variability of honey bees. Tekirdag Ziraat Fakültesi Dergisi, 4(1):7-16, 2007.

Klockars, T. \& Pitkäranta, A. Pediatric tongue-tie division: Indications, techniques and patient satisfaction. Int. J. Pediatr. Otorhinolaryngol., 73(10):1399-1401, 2009.

Kotlow, L. A. Ankyloglossia (tongue-tie): a diagnostic and treatment quandary. Quintessence Int., 30(4):259-62, 1999.

Marchesan, I. Q. Lingual frenulum: quantitative evaluation proposal. Int. J. Orofacial Myology, 31:39-48, 2005.

Messner, A. H.; Lalakea, M. L.; Aby, J.; Macmahon, J. \& Bair, E. Ankyloglossia:incidence and associated feeding difficulties. Arch. Otolaryngol. Head Neck Surg., 126(1):36-9, 2000.

Monteiro, L. R. Why morphometrics is special: The problem with using partial wraps as characters for phylogenetic inference. Syst. Biol., 49(4):796-800, 2000.
Reamy, B. V.; Derby, R. \& Bunt, C. W. Common tongue conditions in primary care. Am. Fam. Physicianac., 81(5):627-34, 2010.

Ricke, L. A.; Baker, N. J.; Madlon-Kay, D. J. \& DeFor, T. A. Newborn tongue-tie:prevalence and effect on breastfeeding. J. Am. Board Fam. Pract., 18(1):1-7, 2005.

\section{Correspondence to: \\ Cagatay Barut \\ Associate Professor \\ Department of Anatomy \\ School of Medicine \\ Zonguldak Karaelmas University \\ 67600 , Zonguldak \\ TURKEY}

Fax: +90 3722610264

Email: cagbarut@yahoo.com

Received: 25-11-2010

Accepted: 14-03-2011 